
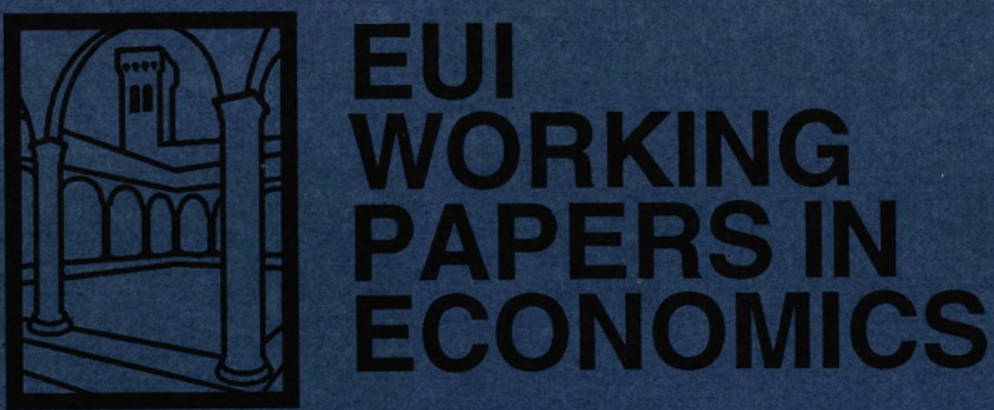

EUI Working Paper ECO No. 93/21

Product Differentiation, Market Structure and Exchange Rate Passthrough

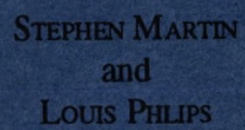

European University Institute, Florence 


\section{EUROPEAN UNIVERSITY INSTITUTE, FLORENCE}

ECONOMICS DEPARTMENT

EUI Working Paper ECO No. 93/21

Product Differentiation, Market Structure and

Exchange Rate Passthrough

STEPHEN MARTIN

and

LOUIS PHLIPS

BADIA FIESOLANA, SAN DOMENICO (FI) 
All rights reserved.

No part of this paper may be reproduced in any form without permission of the authors.

(C) Stephen Martin and Louis Phlips

Printed in Italy in April 1993

European University Institute

Badia Fiesolana

I - 50016 San Domenico (FI)

Italy 
Product Differentiation, Market Structure and Exchange Rate Passthrough

\title{
Stephen Martin
}

\section{Louis Phlips}

\author{
Department of Economics \\ European University Institute \\ 50016 San Domenico di Fiesole \\ Florence, Italy
}

October 1992

We are grateful to participants at the September 1992 EARIE meeting for useful comments. Responsibility for errors is our own. 
JEL Codes: F12, D43, L13

\section{Abstract:}

The impact of changes in the number of foreign/domestic firms, in the extent of product differentiation, and of use of price-setting vs. quantity-setting behavior on the passthrough of exchange rate fluctuations is examined for trade hetween oligopolistic markets with and without economies of scale. 


\section{Introduction}

One of the questions addressed in the growing literature on the consequences of imperfect competition for trade flows is the relationship between market structure and the passthrough of fluctuations in exchange rates to domestic prices.

Like Dornbusch [1987, p. 93], we assume an exogenous movement in the nominal exchange rate. This movement causes a change in the relative costs of foreign and domestic firms, leading to a shift of the reaction surfaces of foreign firms and movements along the reaction surfaces of domestic firms. Our model, like that of Dornbusch, allows us to investigate the impact of changes in market concentration (the number of firms) on the magnitude of passthrough effects. We allow foreign goods to be imperfect substitutes or complements for domestic goods, which permits us to examine the way changes in demand relationships affect the passthrough relationship. Extensions of the model examine the impact of price-setting behavior and of economies of scale on exchange rate passthroughs. ${ }^{1}$

\section{The Basic Model}

1. Substitutability Between Domestic and Foreign Varieties

Consider a partial equilibrium model of trade between 2 countries, A and B. There are $n_{A}$ firms in the country $\mathrm{A}$ industry and $n_{B}$ firms in the country $\mathrm{B}$ industry.

We want to treat the case of differentiated products. Starting from the case of linear (inverse) demand with homogeneous products,

$$
p=a-Q,
$$


a straightforward generalization is to write an inverse demand curve for the variety of a differentiated product group sold by firm Al in market $\mathrm{A} \mathrm{as}^{2}$

$$
p_{A I}=a-\left[q_{A I}+\theta\left(\sum_{i=2}^{n_{A}} q_{A i}+\sum_{j=1}^{n_{B}} x_{B j}\right)\right] \text {. }
$$

In this specification, $\theta$ is a product differentiation parameter. $\theta=1$ implies that products are perfect substitutes (i.e., reduces to (1)), while $\theta=0$ means goods are completely independent in demand. $\theta<0$ covers the case of complementary goods. Without loss of generality, the slope coefficient of $q_{1}$ is normalized at -1 .

With a specification of this kind, it is natural to ask how changes in $\theta$ affect market equilibrium. For our specific purpose, it is natural to ask how changes in $\theta$ affect the equilibrium passthrough of exchange rate fluctuations to domestic prices. But (2) has the implication that an increase in $\theta$ means (a) foreign goods become better substitutes for variety A1; and simultaneously (b) all other domestic varieties become better substitutes for variety A1. The way a change in $\theta$ affects the exchange rate passthrough (and, indeed, other structure-conduct-performance relationships) therefore depends on aspects of both domestic and foreign market structure.

To avoid this convolution of demand-side relationships, when we examine substitute goods we generalize (2) to obtain inverse demand curves which permit the degree of substitutability among domestic varieties and the degree of substitutability between domestic and foreign varieties to differ:

$$
p_{A i}=a-\left(q_{A I}+\theta \sum_{k \neq i}^{n_{A}} q_{A k}+\psi \sum_{j=1}^{n_{B}} x_{B j}\right), i=1, \ldots, n_{A}
$$




$$
p_{B j}=a-\left(x_{B j}+\Psi \sum_{i=1}^{n_{A}} q_{A i}+\theta \sum_{k \neq j}^{n_{B}} x_{B j}\right), j=1,2, \ldots, n_{B}
$$

$P_{A i}$ is the country A price, and $q_{A i}$ the country A sales, of country A firm i; $p_{B j}$ is the country A price, and $x_{B j}$ the country A sales, of country B firm $j$. As in (2), $\theta$ is a product differentiation parameter, now specific to domestic varieties, lying between zero and one. $\Psi$, also lying between zero and one, measures the degree of differentiation between domestic and foreign varieties in the country A market. We assume $\theta>\boldsymbol{\Psi}$ : domestic varieties are better substitutes for one another than are foreign varieties.

We begin with the case of constant marginal cost. This implies that profit-maximizing behavior in each market can be examined separately. We will henceforth focus on country A.

Whether products are strategic substitutes or strategic complements depends on the sign of (for example)

$$
\frac{\partial}{\partial q_{A k}}\left(\frac{\partial \pi_{A I}}{\partial q_{A I}}\right) \quad \text { or } \quad \frac{\partial}{\partial q_{B j}}\left(\frac{\partial \pi_{A I}}{\partial q_{A I}}\right)
$$

(Bulow, Geanakoplos, and Klemperer [1985]). If derivatives of the form (4) are negative. an increase in a rival firm's sales reduces the marginal profitability of firm $\mathrm{Ai}$. The varieties are then strategic substitutes. If the derivatives are positive, an increase in a rival firm's sales increases the marginal profitability of firm $\mathrm{Ai}$. For the linear inverse demand curves (3) and constant marginal cost, these derivatives are negatively proportional to $\theta$ (if the outer derivative is with respect to a domestic variety) or $\Psi$ (if the outer derivative is with respect 
to a foreign variety). This specification has two advantages. First, demand and strategic substitutability (complementarity) coincide. Second, strategic complementarity $(\boldsymbol{\Psi}<0)$ is not ruled out with linear demands, in contrast with the case of linear demand curves and homogeneous commodities (see Kirman and Phlips [1992, p. 4]).

\section{Demand Curves}

Let the country A currency be pounds, the country B currency be dollars, and the exchange rate $e$ the number of pounds per dollar. An increase in $e$ therefore represents a depreciation of the country A currency.

Let $c_{A}$ be the marginal cost of a country A firm, measured in pounds, and $c_{B}$ the marginal cost of a country B firm, measured in dollars. $t_{B A}$ is unit tariff and transportation cost, also measured in dollars, incurred shipping from B to A. $c_{B}+t_{B A}$ is the marginal cost of a country B firm to supply a unit of output to country A. In what follows, we assume $a>c_{A}$ and $a>e\left(c_{B}+t_{B S}\right)$.

Firm Ai's pound profit in country $A$ is

$$
\pi_{A i}=\left(p_{A i}-c_{A}\right) q_{A i}
$$

The dollar profit of country B firm Bj from sales in country A is

$$
\pi_{B j}=\frac{1}{e}\left(p_{B j}-z\right) x_{B j}
$$

where for notational convenience we write $z=e\left(c_{B}+t_{B}\right)$. 
III. Quantity-setting firms

\section{Reaction Functions}

Consider first the case of substitute goods: $\theta>\Psi>0$. Substituting from the inverse demand curve (3a) in (5) gives an expression for firm Ai's profit in terms of its own output and the outputs of other firms. Maximization of this expression with respect to $\mathrm{G}_{A}$ gives the equation of firm $A i$ 's quantity reaction function in country $\mathrm{A}$ :

$$
2 q_{A i}+\theta \sum_{k \neq i}^{n_{A}} q_{A k}+\psi \sum_{j=1}^{n_{B}} x_{B j}=a-c_{A} .
$$

In the same way, firm $\mathrm{Bj}$ 's quantity reaction function in country $\mathrm{A}$ is

$$
2 x_{B j}+\Psi \sum_{i=1}^{n_{A}} q_{A i} \div \theta \sum_{k \neq j}^{n_{B}} x_{B j}=a-z
$$

Now impose country-specific symmetry: since all country A firms produce with the same cost, and all country B firms produce with the same cost, in equilibrium $q_{A i}=q_{1}$ and $x_{B j}=x_{B}$. By imposing these conditions outside of equilibrium, it becomes possible to graph condensed reaction curves that determine country A equilibrium. The equations of the condensed reaction curves are

$$
\left[2+\left(n_{A}-1\right) \theta\right] q_{A}+n_{B} \psi x_{B}=a-c_{A}
$$




$$
n_{A} \Psi q_{A}+\left[2+\left(n_{B}-1\right) \theta\right] x_{B}=a-z
$$

They are graphed in Figure 1.

Two types of conditions must be met for the condensed reaction functions to have the indicated configuration, implying positive equilibrium outputs for firms of both countries. For the country A reaction curve to be steeper than the country B reaction curve, it must be that

$$
D E T 1=(2-\theta)\left[2+\left(n_{A}+n_{B}-1\right) \theta\right]+n_{A} n_{B}\left(\theta^{2}-\psi^{2}\right)>0 .
$$

For the intercepts of the reaction curves to have the indicated relationship, it must be that

$$
\begin{aligned}
& {\left[1+\left(n_{B}-1\right) \theta\right]\left(a-c_{A}\right)-\Psi n_{B}(a-z)>0} \\
& {\left[1+\left(n_{A}-1\right) \theta\right](a-z)-\Psi n_{A}\left(a-c_{A}\right)>0 .}
\end{aligned}
$$

2

These conditions are met provided that there is positive demand for each variety if all varieties price at marginal cost, ${ }^{3}$ which we henceforth assume.

Equilibrium sales are

$$
q_{A}=\frac{\left[2+\left(n_{B}-1\right) \theta\right]\left(a-c_{A}\right)-\psi n_{B}(a-z)}{D E T 1}
$$




$$
x_{B}=\frac{\left[2+\left(n_{A}-1\right) \theta\right](a-z)-\psi n_{A}\left(a-c_{A}\right)}{D E T 1} .
$$

Country-specific symmetry implies that in equilibrium all country A firms will charge the same price and all country B firms will charge the same price. Substituting from (11) into the equations of the inverse demand curves, we obtain country A equilibrium prices for Cournot quantity-setting oligopoly with imperfectly substitutable goods: ${ }^{4}$

$$
\begin{aligned}
& p_{A}=c_{A}+\frac{\left[2+\left(n_{B}-1\right) \theta\right]\left(a-c_{A}\right)-n_{B} \Psi(a-z)}{D E T 1} \\
& p_{B}=z+\frac{\left[2+\left(n_{A}-1\right) \theta\right](a-z)-n_{A} \Psi\left(a-c_{A}\right)}{D E T 1} .
\end{aligned}
$$

\section{Exchange Rate Comparative Statics}

Exchange rate fluctuations translate into proportional fluctuations in $z=e\left(c_{B}+t_{B r}\right)$. From (12),

$$
\begin{gathered}
\frac{\partial p_{A}}{\partial z}=\frac{n_{B} \Psi}{D E T 1}>0 \\
\frac{\partial p_{B}}{\partial z}=1-\frac{2+\left(n_{A}-1\right) \theta}{D E T 1} .
\end{gathered}
$$


A little algebra shows that

$$
1>\frac{\partial p_{B}}{\partial z}>0 .
$$

For substitute goods, a depreciation of the home-country currency results in a partial increase in the price of foreign goods and what might be termed a sympathetic increase in the price of competing domestic goods. From (13) and (14), we obtain

$$
\begin{gathered}
\frac{\partial p_{B}}{\partial z}-\frac{\partial p_{A}}{\partial z}= \\
\frac{(2-\theta)\left[2+\left(n_{A}+n_{B}+1\right) \theta\right]+n_{B}\left[1+n_{A}(\theta+\psi)\right](\theta-\Psi)}{D E T 1}>0 .
\end{gathered}
$$

An increase in e leads to a relative increase in price of foreign goods.

The magnitude of passthrough effects depends on $n_{A}, n_{B}, \theta$, and $\Psi$. From (13),

$$
\begin{gathered}
\frac{\partial}{\partial n_{A}}\left(\frac{\partial p_{A}}{\partial z}\right)=-\frac{n_{B} \Psi}{D E T 1^{2}}\left[(2-\theta) \theta+n_{B}\left(\theta^{2}-\Psi^{2}\right)\right]<0 ; \\
\frac{\partial}{\partial n_{B}}\left(\frac{\partial p_{A}}{\partial z}\right)=\Psi \frac{(2-\theta)\left[2+\left(n_{A}-1\right) \theta\right]}{D E T 1^{2}}>0 ; \\
\frac{\partial}{\partial \theta}\left(\frac{\partial p_{A}}{\partial z}\right)=-2 \frac{n_{B} \Psi}{D E T 1^{2}}\left[n_{A}+n_{B}-2+\theta\left(n_{A}-1\right)\left(n_{B}-1\right)\right]<0 ;
\end{gathered}
$$




$$
\frac{\partial}{\partial \Psi}\left(\frac{\partial p_{A}}{\partial z}\right)=n_{B} \frac{(2-\theta)\left[2+\left(n_{A}+n_{B}-1\right) \theta\right]+n_{A} n_{B}\left(\theta^{2}+\psi^{2}\right)}{D E T 1^{2}}>0 .
$$

As the number of domestic firms increases, the number of firms in the market whose relative costs are not directly affected by exchange rate fluctuations goes up and the magnitude of the passthrough of exchange rate fluctuations to the prices of domestic varieties goes down. Among the other effects which may be laid at the feet of a concentrated market is an enhanced sensibility to exchange rate fluctuations. On the other hand. an increase in $n_{B}$ increases the passthrough to prices of domestic varieties because it increases the number of varieties whose relative costs are directly affected by exchange rate fluctuations.

As $\theta$ increases, domestic varieties become better and better substitutes one for another. As a result, the common equilibrium price of domestic varieties falls toward $c_{A}$. This means that there is less of a range within which exchange rate fluctuations can affect prices of domestic varieties. As $\boldsymbol{\psi}$ increases, foreign varieties become better substitutes for domestic varieties, so exchange rate fluctuations have a greater impact on $p_{1}$. The fact that $(17 c)$ and (17d) are of opposite sign explains why $\partial p_{A} / \partial \theta$ is of ambiguous sign if $\theta$ and $\Psi$ are constrained to be equal.

As regards the passthrough to the country A price of country B varieties, we have from (14),

$$
\frac{\partial}{\partial n_{A}}\left(\frac{\partial p_{B}}{\partial z}\right)=-\frac{n_{B} \psi^{2}(2-\theta)}{D E T 1^{2}}<0
$$




$$
\begin{gathered}
\frac{\partial}{\partial n_{B}}\left(\frac{\partial p_{B}}{\partial z}\right)=\left[2+\left(n_{A}-1\right) \theta\right] \frac{\theta(2-\theta)+n_{A}\left(\theta^{2}-\Psi^{2}\right)}{D E T 1^{2}}>0 ; \\
\frac{\partial}{\partial \theta}\left(\frac{\partial p_{B}}{\partial z}\right)=\frac{\left(n_{A}-1\right) n_{A} n_{B} \Psi^{2}+\left[2+\left(n_{A}-1\right) \theta\right]\left(n_{B}-1\right)}{D E T 1^{2}}>0 ;
\end{gathered}
$$

As the number of domestic firms increases, or the number of foreign firms decreases, the impact of exchange rate fluctuations on the prices of foreign varieties decreases. As domestic varieties become better substitutes one for another, and as foreign varieties become better substitutes for domestic varieties, the magnitude of $\partial p_{B} / \partial z$ goes up.

\section{Complementary Goods}

\section{The Model}

We examine the case in which all domestic varieties are substitutes, all foreign varieties are substitutes, but foreign and domestic varieties are complements.s For expositional convenience, we substitute $\phi=-\downarrow$ in the demand curves (3). $\phi$ lies between zero and one, and is the degree of complementarity between domestic and foreign goods. An increase in $\phi$ means an increase in the complementarity between foreign and domestic varieties. 
2. Exchange Rate Comparative Statics

When foreign and domestic varieties are complements, the condensed reaction curves of quantity-setting firms slope upward. The slope and intercept conditions for the existence of positive equilibrium outputs for firms in both countries are derived in a straightforward way. Equilibrium prices are

$$
\begin{aligned}
& p_{A}=c_{A}+\frac{\left[2+\left(n_{B}-1\right) \theta\right]\left(a-c_{A}\right)+n_{B} \phi(a-z)}{D E T l} \\
& p_{B}=z+\frac{\left[2+\left(n_{A}-1\right) \theta\right](a-z)+n_{A} \phi\left(a-c_{A}\right)}{D E T 1} .
\end{aligned}
$$

Thus

$$
\begin{gathered}
\frac{\partial p_{A}}{\partial z}=-\frac{n_{B} \phi}{D E T 1}<0 \\
\frac{\partial p_{B}}{\partial z}=1-\frac{2+\left(n_{A}-1\right) \theta}{D E T 1}
\end{gathered}
$$

The signs of the comparative static partial derivatives (17b), (17c), and (17d) are reversed. The sign of (17a) is positive if $\theta^{2} \succeq \phi^{2}$. (18a) remains negative, and (18d) remains positive if $\theta^{2} \succeq \phi^{2}$. (18c) and (18b) change sign. 
V. Price-setting firms

1. The Model

To model price-setting firms, it is necessary to solve the system of inverse demand curves and obtain the implied demand curves. As suggested by (5) and (6), it is convenient to express the quantity demanded as a function of deviations of price from marginal cost. For notational compactness, we will write

$$
p_{A i}^{*}=p_{A i}-c_{A} \quad p_{B j}^{*}=p_{B j}-z
$$

where $z=e\left(c_{B}+t_{B}\right)$.

Demand curves are then (see Appendix)

$$
\begin{aligned}
(1-\theta) D q_{A k}= & \left\{\left[1+\left(n_{B}-1\right) \theta\right]\left(a-c_{A}\right)-n_{B} \Psi(a-z)\right\}+\left(\theta+n_{B} \frac{\theta^{2}-\Psi^{2}}{1-\theta}\right)_{i \neq k}^{n_{A}} p_{A i}^{*} \\
& +\Psi \sum_{j=1}^{n_{B}} p_{B j}^{*}-\left[1+\left(n_{A}+n_{B}-2\right) \theta+\left(n_{A}-1\right) n_{B} \frac{\theta^{2}-\Psi^{2}}{1-\theta} p_{A k}^{*}\right.
\end{aligned}
$$

$$
\begin{aligned}
(1-\theta) D x_{B k} & =\left\{\left[1+\left(n_{A}-1\right) \theta\right](a-z)-n_{A} \Psi\left(a-c_{A}\right)\right\}+\left(\theta+n_{A} \frac{\theta^{2}-\Psi^{2}}{1-\theta}\right) \sum_{j \neq k}^{n_{B}} p_{B j}^{*} \\
& +\Psi \sum_{i=1}^{n_{A}} p_{A i}^{*}-\left[1+\left(n_{A}+n_{B}-2\right) \theta+n_{A}\left(n_{B}-1\right) \frac{\theta^{2}-\psi^{2}}{1-\theta} p_{B k}^{*}\right.
\end{aligned}
$$


where

$$
D=(1-\theta)\left[1+\left(n_{A}+n_{B}-1\right) \theta\right]+n_{A} n_{B} \frac{\theta^{2}-\psi^{2}}{1-\theta}>0
$$

\section{Reaction Functions}

Return to the case of substitute varieties. Using the demand curves (23a) and (23b) to express profits (5) and (6) in terms of prices, the equations of the price reaction curves of firms $\mathrm{A} 1$ and $\mathrm{B} 1$ are

$$
\begin{gathered}
2\left[1+\left(n_{A}+n_{B}-2\right) \theta+\left(n_{A}-1\right) n_{B} \frac{\theta^{2}-\psi^{2}}{1-\theta}\right]\left(p_{A l}-c_{A}\right) \\
-\left(\theta+n_{B} \frac{\theta^{2}-\psi^{2}}{1-\theta}\right) \sum_{i=2}^{n_{A}}\left(p_{A i}-c_{A}\right)-\psi \sum_{j=1}^{n_{B}}\left(p_{B j}-z\right)= \\
{\left[1+\left(n_{B}-1\right) \theta\right]\left(a-c_{A}\right)-\psi n_{B}(a-z)}
\end{gathered}
$$

and

$$
\begin{gathered}
2\left[1+\left(n_{A}+n_{B}-2\right) \theta+n_{B}\left(n_{A}-1\right) \frac{\theta^{2}-\psi^{2}}{1-\theta}\right]\left(p_{B 1}-z\right) \\
-\psi \sum_{i=1}^{n_{A}}\left(p_{A i}-c_{A}\right)-\left(\theta+n_{A} \frac{\theta^{2}-\psi^{2}}{1-\theta}\right) \sum_{j=2}^{n_{B}}\left(p_{B j}-z\right)= \\
{\left[1+\left(n_{A}-1\right) \theta\right](a-z)-n_{A} \psi\left(a-c_{A}\right)}
\end{gathered}
$$

respectively.

Imposing country-specific symmetry in (25), we obtain the equations of condensed price-reaction functions for country A firms and country B firms in country A: 


$$
\begin{aligned}
& {\left[2+\left(n_{A}+2 n_{B}-3\right) \theta+\left(n_{A}-1\right) n_{B} \frac{\theta^{2}-\psi^{2}}{1-\theta}\right]\left(p_{A}-c_{A}\right) } \\
- & n_{B} \psi\left(p_{B}-z\right)=\left[1+\left(n_{B}-1\right) \theta\right]\left(a-c_{A}\right)-\psi n_{B}(a-z) ; \\
& {\left[2+\left(2 n_{A}+n_{B}-3\right) \theta+n_{A}\left(n_{B}-1\right) \frac{\theta^{2}-\psi^{2}}{1-\theta}\right]\left(p_{B}-z\right) } \\
- & n_{A} \psi\left(p_{A}-c_{A}\right)=\left[1+\left(n_{A}-1\right) \theta\right](a-z)-n_{A} \psi\left(a-c_{A}\right) .
\end{aligned}
$$

The condensed reaction curves are graphed in Figure 2. From (23), the intercepts of the reaction curves with the lines $p_{B}=z, p_{A}=c_{A}$ have the indicated configuration provided that there is positive demand for each variety if all varieties price at marginal cost.

The existence of equilibrium requires that the slope of the country A firm reaction function be greater than 1 , while the slope of the country B firm reaction function is less than one. This requires that

$$
\begin{gathered}
D E T 2=\left[2+\left(n_{A}+2 n_{B}-3\right) \theta+\left(n_{A}-1\right) n_{B} \frac{\theta^{2}-\psi^{2}}{1-\theta}\right]\left[2+\left(2 n_{A}+n_{B}-3\right) \theta+n_{A}\left(n_{B}-1\right) \frac{\theta^{2}-\psi^{2}}{1-\theta}\right] \\
-n_{A} n_{B} \Psi^{2}>0 .
\end{gathered}
$$

which we henceforth assume. 
3. Exchange Rate Comparative Statics

From (26), one obtains the equilibrium prices when firms set prices:

$$
\begin{gathered}
\operatorname{DET2}\left(p_{A}-c_{A}\right)= \\
\left\{\left[2+\left(2 n_{A}+n_{B}-3\right) \theta+n_{A}\left(n_{B}-1\right) \frac{\theta^{2}-\psi^{2}}{1-\theta}\right]\left[1+\left(n_{B}-1\right) \theta\right]-n_{A} n_{B} \psi^{2}\right\}\left(a-c_{A}\right)(28 \mathrm{a}) \\
-n_{B} \psi\left[1+\left(n_{A}+n_{B}-2\right) \theta+n_{A}\left(n_{B}-1\right) \frac{\theta^{2}-\psi^{2}}{1-\theta}\right](a-z) \\
\left\{\left[\begin{array}{c}
D E T 2\left(p_{B}-z\right)= \\
\left.\left.-\left(n_{A}+2 n_{B}-3\right) \theta+\left(n_{A}-1\right) n_{B} \frac{\theta^{2}-\psi^{2}}{1-\theta}\right]\left[1+\left(n_{A}-1\right) \theta\right]-n_{A} n_{B} \psi^{2}\right\}(a-z)(28 \mathrm{~b}) \\
\left.-n_{A} \Psi+\left(n_{A}+n_{B}-2\right) \theta+\left(n_{A}-1\right) n_{B} \frac{\theta^{2}-\psi^{2}}{1-\theta}\right]\left(a-c_{A}\right)
\end{array}\right.\right.
\end{gathered}
$$

From (28), we have

$$
\frac{\partial p_{A}}{\partial z}=\frac{n_{B} \psi\left[1+\left(n_{A}+n_{B}-2\right) \theta+n_{A}\left(n_{B}-1\right) \frac{\theta^{2}-\psi^{2}}{1-\theta}\right]}{D E T 2}>0
$$

$$
\begin{gathered}
\frac{\partial p_{B}}{\partial z}= \\
\frac{\left[1+\left(n_{A}+n_{B}-2\right) \theta+n_{A}\left(n_{B}-1\right) \frac{\theta^{2}-\Psi^{2}}{1-\theta}\right]\left[2+\left(n_{A}+2 n_{B}-3\right) \theta+\left(n_{A}-1\right) n_{B} \frac{\theta^{2}-\psi^{2}}{1-\theta}\right]}{D E T 2}
\end{gathered}
$$


As in the yuantity-setting case, $(29 \mathrm{~b})$ lies between zero and one. Similarly

$$
\frac{\frac{\partial p_{B}}{\partial z}-\frac{\partial p_{A}}{\partial z}=}{\left[1+\left(n_{A}+n_{B}-2\right) \theta+n_{A}\left(n_{B}-1\right) \frac{\theta^{2}-\psi^{2}}{1-\theta}\right]\left[2+\left(n_{A}+n_{B}-3\right) \theta+n_{B}(\theta-\psi)+\left(n_{A}-1\right) n_{B} \frac{\theta^{2}-\psi^{2}}{1-\theta}\right]}>0,
$$

Whether firms set prices or quantities, an increase in $e$ leads to a relative increase in price of foreign goods. ${ }^{6}$

\section{Complementary Goods}

The condensed reaction curves for price-setting firms slope upward when foreign and domestic varieties are complements. The intercept conditions for equilibrium prices to exceed marginal cost for firms in both countries imply, among other things, that

$$
\begin{aligned}
& 1+\left(n_{A}+n_{B}-2\right) \theta+n_{A}\left(n_{B}-1\right) \frac{\theta^{2}-\phi^{2}}{1-\theta} \geq 0 \\
& 1+\left(n_{A}+n_{B}-2\right) \theta+\left(n_{A}-1\right) n_{B} \frac{\theta^{2}-\phi^{2}}{1-\theta} \geq 0
\end{aligned}
$$


which imply that

$$
\begin{gathered}
\frac{\partial p_{A}}{\partial z}=-\frac{n_{B} \phi\left[1+\left(n_{A}+n_{B}-2\right) \theta+n_{A}\left(n_{B}-1\right) \frac{\theta^{2}-\Psi^{2}}{1-\theta}\right]}{D E T 2}<0 \\
\frac{\frac{\partial p_{B}}{\partial z}=}{\left[1+\left(n_{A}+n_{B}-2\right) \theta+n_{A}\left(n_{B}-1\right) \frac{\theta^{2}-\psi^{2}}{1-\theta}\right]\left[2+\left(n_{A}+2 n_{B}-3\right) \theta+\left(n_{A}-1\right) n_{B} \frac{\theta^{2}-\psi^{2}}{1-\theta}\right]}>0
\end{gathered}
$$

\section{Economies of scale}

1. The model

If increases in output reduce marginal cost, the effect should be to reduce the magnitude of the passthrough of exchange rate fluctuations to domestic prices. Ihe intuition is straightforward: even if an exchange rate movement reduces the revenue that a country B firm earns from its sales in country A, the country B firm will have an incentive to maintain its sales in country A, for the sake of the cost reductions that those sales generate. This means that output will fluctuate less than would otherwise be the case. But if economies of scale reduce the impact of exchange rate fluctuations on output, they reduce the impact of exchange rate fluctuations on price.

It suffices to demonstrate this effect in the simplest possible model. Suppose one firm in country A and one firm in country B produce a homogeneous product. Assume tariffs and 
transportation costs are zero, and let the cost functions of the country A firm and the country B firm be

$$
\begin{aligned}
& C_{A}\left(q_{A}, x_{A}\right)=c_{A}\left(q_{A}+x_{A}\right)-d\left(q_{A}^{2}+x_{A}^{2}\right) \\
& C_{B}\left(q_{B}, x_{B}\right)=c_{B}\left(q_{B}+x_{B}\right)-\delta\left(q_{B}^{2}+x_{B}^{2}\right)
\end{aligned}
$$

respectively. By assuming $\mathrm{d}, \delta>0$, we obtain a model in which increases in output reduce marginal cost. By making these cost reductions functions of the squares of output in each country, we once again obtain a model in which country A and country B sales decisions can be analyzed separately. ${ }^{7}$ We also assume that $\mathrm{d}$ and $\delta$ are sufficiently small so that both firms produce positive outputs in equilibrium.

2. Quantity-setting equilibrium

Given our assumption that products are homogeneous, we confine ourselves to the analysis of quantity-setting behavior. The equations of the country A reaction functions are

$$
\begin{gathered}
2(1-d) q_{A}+x_{B}=a-c_{A} \\
q_{A}+2(1-\delta) x_{B}=a-e c_{B} .
\end{gathered}
$$

Solving (34), equilibrium outputs are

$$
q_{A}=\frac{2(1-e \delta)\left(a-c_{A}\right)-\left(a-e c_{B}\right)}{D E T_{A}}
$$




$$
x_{A}=\frac{2(1-d)\left(a-e c_{B}\right)-\left(a-c_{A}\right)}{D E T_{A}},
$$

where $D E T_{A}=4(I-d)(I-\delta)-1$. We will assume that $d$ and $\delta$ are sufficiently small so that $D E T_{A}>0$.

In equilibrium, total output is

$$
q_{A}+x_{A}=\frac{(1-2 e \delta)\left(a-c_{A}\right)+(1-2 d)\left(a-e c_{B}\right)}{D E T_{A}}
$$

Substituting the results into the equation of the market demand curve, Cournot equilibrium price is

$$
p_{A}=c_{A}+(1-2 d) \frac{2(1-e \delta)\left(a-c_{A}\right)-\left(a-e c_{B}\right)}{D E T_{A}}
$$

or equivalently

$$
p_{A}=e c_{B}+(1-2 e \delta) \frac{2(1-d)\left(a-e c_{B}\right)-\left(a-c_{A}\right)}{D E T_{A}} .
$$

\section{Exchange Rate Comparative Statics}

It is easiest to understand the impact of exchange rate fluctuations on equilibrium price by examining the impact of exchange rate fluctuations on equilibrium outputs. From 
equations (35),

$$
\begin{gathered}
\frac{\partial q_{A}}{\partial e}=\frac{c_{B}}{D E T_{A}}-4 \delta(1-d) \frac{a-e c_{B}}{D E T_{A}^{2}} \\
\frac{\partial x_{A}}{\partial e}=-2(1-\delta) \frac{c_{B}}{D E T_{A}}+4 \delta(1-d) \frac{2(1-d)\left(a-e c_{B}\right)-\left(a-c_{A}\right)}{D E T_{A}^{2}} \\
\frac{\partial\left(q_{A}+x_{B}\right.}{\partial e}=2(1-d)\left[-\frac{c_{B}}{D E T_{A}}+2 \delta \frac{2(1-d)\left(a-e c_{B}\right)-\left(a-c_{A}\right)}{D E T_{A}^{2}}\right]
\end{gathered}
$$

From equations (37) and for $\mathrm{d}, \delta$ sufficiently small, an increase in e (a depreciation of the country A currency) causes the equilibrium exports of the country B firm to country A to fall, but not by as much as if returns to scale were constant. This reflects a shift in the country B reaction curve and a movement of equilibrium along the country A reaction curve. The equilibrium output of the country A firm rises, but not by as much as if returns to scale were constant. Total output falls, but not by as much as if returns to scale were constant.

The presence of economies of scale moderates the impact of exchange rate changes on output. This tends to stabilize country A price:

$$
\frac{1}{1-2 d} \frac{\partial p_{A}}{\partial e}=\frac{c_{B}}{D E T_{A}}-2 \delta \frac{2(1-d)\left(a-e c_{B}\right)-\left(a-c_{A}\right)}{D E T_{A}^{2}}
$$

A depreciation of the country A currency causes the country A price to rise. But the increase 


\section{Notes}

1. For simplicity, we ignore the effects of uncertainty. Hooper and Kohlhagen [1978] and Katz, Paroush, and Kahana [1982] incorporate uncertainty in models of exchange rate determination. Neither model is well suited to the examination of the connection between elements of market structure and the nature of passthrough effects.

2. Allowing for notational differences, this is the model of Spence [1976]. It can be investigated for its own sake as a generalization of the homogeneous product linear demand case, or it can be rationalized as the outcome of a utility maximization process by a representative consumer with a quadratic utility function. For discussion of the latter approach, see Kirman [1992].

3. See the equations (23) of the demand curves.

4. Since $\pi_{A l}=\left(p_{A l}-c_{A}\right) q_{A l}$, the equation of firm A1's reaction curve can be written in implicit form as $p_{A I}-c_{A}=q_{A I} \frac{\partial p_{A I}}{\partial q_{A I}}=q_{A I}$. Similarly $p_{B j}-z=q_{B}$, as in (12b).

5. For concreteness, one may consider the case in which $n_{A}$ domestic firms produce pairs of shoes while $\mathrm{n}_{\mathrm{B}}$ foreign firms produce pairs of socks.

6. From (29) it is possible to calculate the comparative static derivatives that correspond to (17) and (18). The resulting expressions are too complex to be signed for general parameter 
is less than would be the case if returns to scale were constant.

\section{Conclusion}

The extent to which exchange rate fluctuations are passed on to domestic prices depends on substitutability/complementarity relationships among varieties produced by domestic and foreign firms and on the extent of economies of scale.

When all varieties are substitutes, the passthrough of exchange rate fluctuations rises with the degree of substitutability. A depreciation of the home country currency causes a relative increase in the prices of foreign varieties. Exchange rate passthroughs are less, all else equal, in unconcentrated markets.

If, on the other hand, foreign varieties are complementary to domestic varieties, a depreciation of the home country currency causes a reduction in the price of domestic varieties. This is the expected effect, since such a depreciation causes complementary foreign varieties to become more expensive.

Further, if firms are able to reduce marginal cost by increasing output, the impact of changes in the exchange rate on outputs and prices is reduced. 
values.

7. The leading alternative specification is to let the coefficient of $d$ be the square of total output of the country A firm and the coefficient of $\delta$ be the square of total output of the country B firm. Analysis of equilibrium in this case will yield results qualitatively similar to those presented here, but requires simultaneous consideration of all four reaction functions. 
Appendix: Derivation of demand curves.

Write the system of inverse demand curves (3) as

$$
\left(\begin{array}{l}
p_{A}^{*} \\
p_{B}^{*}
\end{array}\right)=\left[\begin{array}{c}
\left(a-c_{A}\right) J_{A} \\
(a-z) J_{B}
\end{array}\right]-b M\left(\begin{array}{l}
q_{A} \\
x_{B}
\end{array}\right)
$$

where $\mathrm{p}_{\mathrm{A}}{ }^{*}$ is a column vector of prices of country $\mathrm{A}$ varieties and $\mathrm{p}_{\mathrm{B}}{ }^{*}$ is a column vector of prices of country $B$ varieties, measured in deviations from marginal cost. $J_{A}$ is a column vector of $n_{A}$ ones; $J_{B}$ is a column vector of $n_{B}$ ones. $M$ is the $n$ by $n$ square vector

$$
M=(1-\theta) I_{n}+\left(\begin{array}{ll}
\theta J_{A} J_{A}^{\prime} & \Psi J_{A} J_{B}^{\prime} \\
\Psi J_{B} J_{A}^{\prime} & \theta J_{B} J_{B}^{\prime}
\end{array}\right)
$$

for $n=n_{A}+n_{B}$. Tedious linear algebra shows that

$$
M^{-1}=\frac{1}{1-\theta} I_{n}-\frac{N}{D}
$$

for

$$
N=\left[\begin{array}{ll}
\left(\begin{array}{ll}
\theta+n_{B} \frac{\theta^{2}-\Psi^{2}}{1-\theta}
\end{array}\right) J_{A} J_{A}^{\prime} & \Psi J_{A} J_{B}^{\prime} \\
\Psi J_{B} J_{A}^{\prime} & \left(\theta+n_{A} \frac{\theta^{2}-\Psi^{2}}{1-\theta}\right) J_{B} J_{B}^{\prime}
\end{array}\right]
$$

and D given by (24).Application of the inverse matrix (A4) to the system of equations (A1) yields the demand curves (23). 


\section{References}

Brown, Drusilla K. "Market structure, the exchange rate and pricing behavior of firms: some evidence from computable general equilibrium trade models," Weltwirtschaftliches Archiv Band 125, Heft 3, 1989, pp. 441-463.

Bulow, Jeremy I., Geanakoplos, John D. and Klemperer, Paul D. "Multimarket oligopoly: strategic substitutes and complements," Journal of Political Economy Volume 93, Number 3, June 1985, pp. 488-511.

Dornbusch, Rudiger "Exchange rates and prices," American Economic Review Volume 77, Number 1, March 1987, pp. 93-106.

Hooper, Peter and Kohlhagen, Steven W. "The effect of exchange rate uncertainty on the prices and volume of international trade," Journal of International Economics Volume 8. 1978 , pp. 483-511.

Katz, E., Paroush, J., and Kahana, N. "Price uncertainty and the price discriminating firm in international trade," Journal of International Economics Volume 22.3, Number 2, June 1982 , pp. $389-400$.

Kirman, Alan P. "Whom or what does the representative individual represent?," Journal of Economic Perspectives, Volume 6, Number 2, Spring 1992, pp. 117-136.

Kirman, Alan P. and Phlips, Louis "Exchange rate pass-through and market structure," European University Institute, Department of Economics Working Paper 92/83, 1992.

Spence, A. Michael "Product Differentiation and Welfare," American Economic Review Volume 66, Number 2, May 1976a, pp. 407-414.

Vives, Xavier "On the Efficiency of Bertrand and Cournot Equilibria with Product Differentiation," Journal of Economic Theory Volume 36, 1984, pp. 166-175. 
Figure 1: Condensed quantity reaction curves, Country A

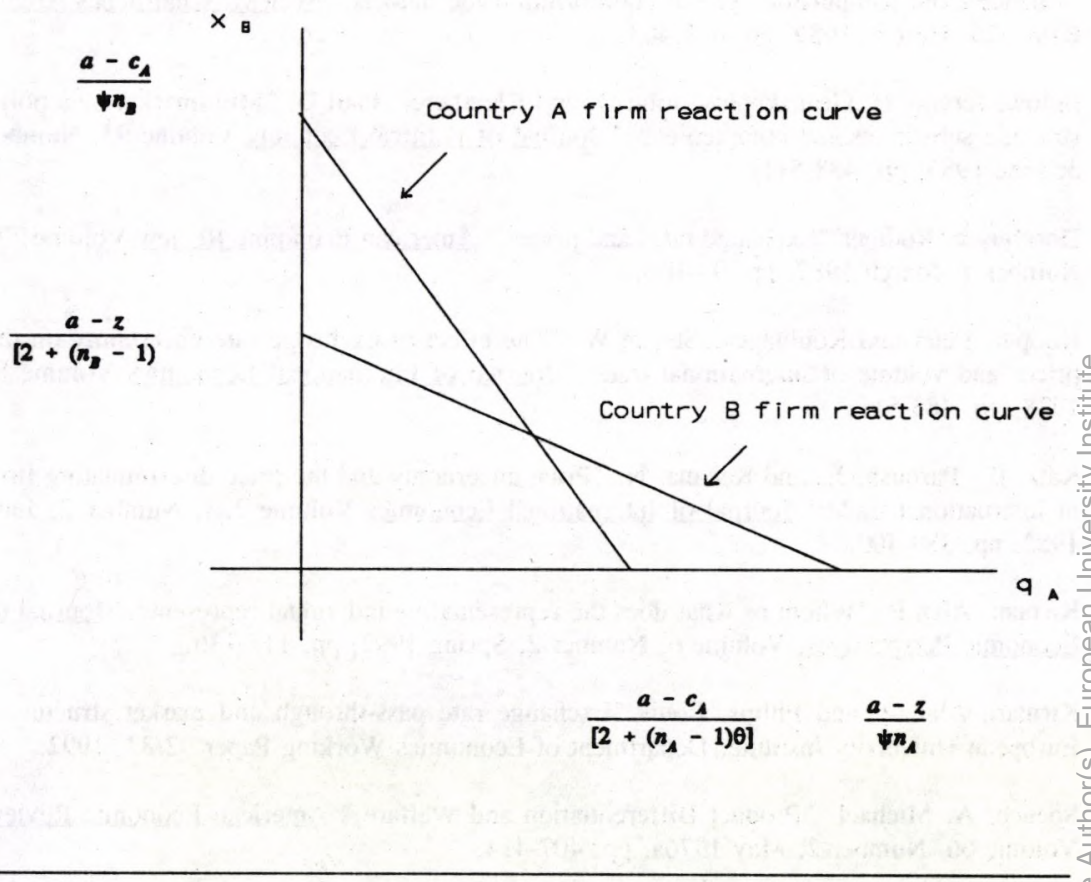


Figure 2: Symmetric reaction curves, Country $\mathrm{A}, \theta>0$.

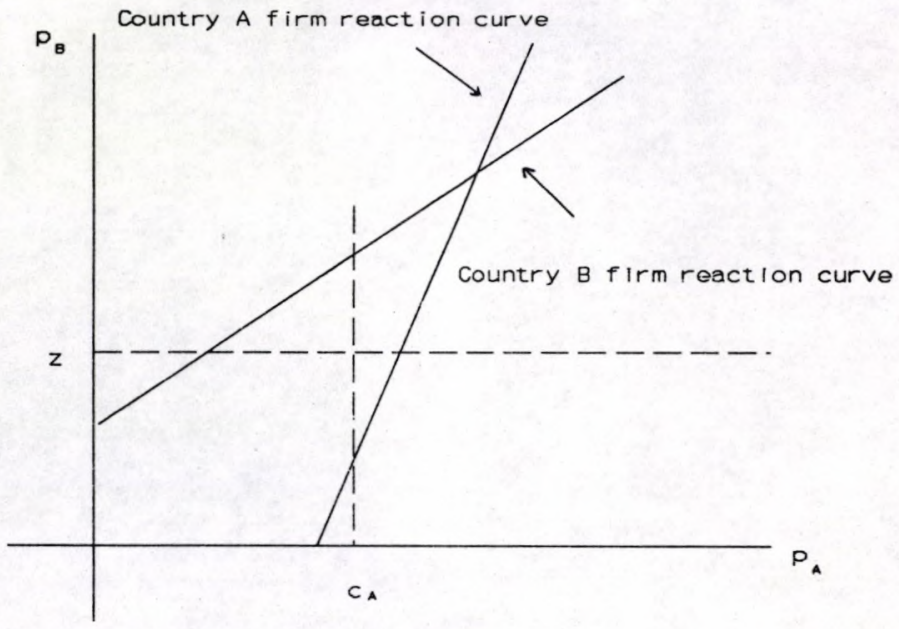




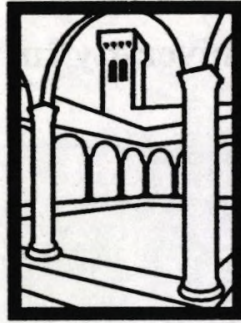

EUI Working Papers are published and distributed by the European University Institute, Florence

Copies can be obtained free of charge - depending on the availability of stocks - from:

The Publications Officer

European University Institute

Badia Fiesolana

I-50016 San Domenico di Fiesole (FI)

Italy 


\section{Publications of the European University Institute}

To

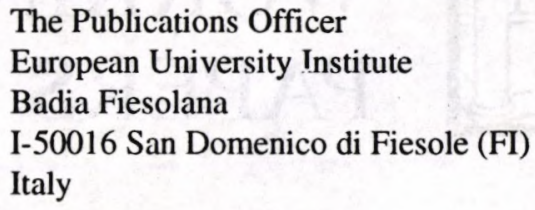

The Publications Officer

European University Institute

Badia Fiesolana

I-50016 San Domenico di Fiesole (FI)

Italy

From

Name

Address.

$\square$ Please send me a complete list of EUI Working Papers

$\square$ Please send me a complete list of EUI book publications

$\square$ Please send me the EUI brochure Academic Year 1993/94

$\square$ Please send me the EUI Research Report

Please send me the following EUI Working Paper(s):

No, Author

Title:

No, Author

Title:

No, Author

Title:

No, Author

Title:

Date

Signature 


\section{Working Papers of the Department of Economics Published since 1990}

ECO No. 90/1

Tamer BASAR and Mark SALMON

Credibility and the Value of Information

Transmission in a Model of Monetary

Policy and Inflation

ECO No. 90/2

Horst UNGERER

The EMS - The First Ten Years

Policies - Developments - Evolution

\section{ECO No. 90/3}

Peter J. HAMMOND

Interpersonal Comparisons of Utility:

Why and how they are and should be made

ECO No. 90/4

Peter J. HAMMOND

A Revelation Principle for (Boundedly)

Bayesian Rationalizable Strategies

ECO No. 90/5

Peter J. HAMMOND

Independence of Irrelevant Interpersonal Comparisons

ECO No. 90/6

Hal R. VARIAN

A Solution to the Problem of

Externalities and Public Goods when

Agents are Well-Informed

ECO No. 90/7

Hal R. VARIAN

Sequential Provision of Public Goods

ECO No. 90/8

T. BRIANZA, L. PHLIPS and J.F.

RICHARD

Futures Markets, Speculation and

Monopoly Pricing

ECO No. 90/9

Anthony B. ATKINSON/ John

MICKLEWRIGHT

Unemployment Compensation and

Labour Market Transition: A Critical

Review

ECO No. 90/10

Peter J. HAMMOND

The Role of Information in Economics
ECO No. 90/11

Nicos M. CHRISTODOULAKIS

Debt Dynamics in a Small Open

Economy

ECO No. 90/12

Stephen C. SMITH

On the Economic Rationale for

Codetermination Law

ECO No. 90/13

Elettra AGLIARDI

Learning by Doing and Market Structures

ECO No. 90/14

Peter J. HAMMOND

Intertemporal Objectives

ECO No. 90/15

Andrew EVANS/Stephen MARTIN

Socially Acceptable Distortion of

Competition: EC Policy on State Aid

ECO No. 90/16

Stephen MARTIN

Fringe Size and Cartel Stability

ECO No. 90/17

John MICKLEWRIGHT

Why Do Less Than a Quarter of the

Unemployed in Britain Receive

Unemployment Insurance?

ECO No. 90/18

Mrudula A. PATEL

Optimal Life Cycle Saving With

Borrowing Constraints:

A Graphical Solution

ECO No. 90/19

Peter J. HAMMOND

Money Metric Measures of Individual and Social Welfare Allowing for

Environmental Externalities

ECO No. 90/20

Louis PHLIPS/

Ronald M. HARSTAD

Oligopolistic Manipulation of Spot

Markets and the Timing of Futures

Market Speculation 
ECO No. 90/21

Christian DUSTMANN

Earnings Adjustment of Temporary

Migrants

ECO No. 90/22

John MICKLEWRIGHT

The Reform of Unemployment

Compensation:

Choices for East and West

ECO No. 90/23

Joerg MAYER

U. S. Dollar and Deutschmark as

Reserve Assets

ECO No. 90/24

Sheila MARNIE

Labour Market Reform in the USSR:

Fact or Fiction?

ECO No. 90/25

Peter JENSEN/

Niels WESTERGÅRD-NIELSEN

Temporary Layoffs and the Duration of

Unemployment: An Empirical Analysis

ECO No. 90/26

Stephan L. KALB

Market-Led Approaches to European

Monetary Union in the Light of a Legal

Restrictions Theory of Money

ECO No. 90/27

Robert J. WALDMANN

Implausible Results or Implausible Data?

Anomalies in the Construction of Value

Added Data and Implications for Esti-

mates of Price-Cost Markups

ECO No. 90/28

Stephen MARTIN

Periodic Model Changes in Oligopoly

ECO No. 90/29

Nicos CHRISTODOULAKIS/

Martin WEALE

Imperfect Competition in an Open

Economy
米米米

ECO No. 91/30

Steve ALPERN/Dennis J. SNOWER

Unemployment Through 'Learning From

Experience'

ECO No. 91/31

David M. PRESCOTT/Thanasis

STENGOS

Testing for Forecastible Nonlinear

Dependence in Weekly Gold Rates of

Return

ECO No. 91/32

Peter J. HAMMOND

Harsanyi's Utilitarian Theorem:

A Simpler Proof and Some Ethical

Connotations

ECO No. 91/33

Anthony B. ATKINSON/

John MICKLEWRIGHT

Economic Transformation in Eastern

Europe and the Distribution of Income*

ECO No. 91/34

Svend ALBAEK

On Nash and Stackelberg Equilibria

when Costs are Private Information

ECO No. 91/35

Stephen MARTIN

Private and Social Incentives

to Form R \& D Joint Ventures

ECO No. 91/36

Louis PHLIPS

Manipulation of Crude Oil Futures

ECO No. 91/37

Xavier CALSAMIGLIA/Alan KIRMAN

A Unique Informationally Efficient and

Decentralized Mechanism With Fair

Outcomes

ECO No. 91/38

George S. ALOGOSKOUFIS/

Thanasis STENGOS

Testing for Nonlinear Dynamics in

Historical Unemployment Series

ECO No. 91/39

Peter J. HAMMOND

The Moral Status of Profits and Other

Rewards:

A Perspective From Modern Welfare

Economics 
ECO No. 91/40

Vincent BROUSSEAU/Alan KIRMAN

The Dynamics of Learning in Mis-

Specified Models

ECO No. 91/41

Robert James WALDMANN

Assessing the Relative Sizes of Industryand Nation Specific Shocks to Output

ECO No. 91/42

Thorsten HENS/Alan KIRMAN/Louis PHLIPS

Exchange Rates and Oligopoly

ECO No. $91 / 43$

Peter J. HAMMOND

Consequentialist Decision Theory and

Utilitarian Ethics

ECO No. 91/44

Stephen MARTIN

Endogenous Firm Efficiency in a Cournot

Principal-Agent Model

ECO No. 91/45

Svend ALBAEK

Upstream or Downstream Information Sharing?

ECO No. 91/46

Thomas H. McCURDY/

Thanasis STENGOS

A Comparison of Risk-Premium

Forecasts Implied by Parametric Versus

Nonparametric Conditional Mean

Estimators

ECO No. 91/47

Christian DUSTMANN

Temporary Migration and the Investment into Human Capital

ECO No. 91/48

Jean-Daniel GUIGOU

Should Bankruptcy Proceedings be

Initiated by a Mixed

Creditor/Shareholder?

ECO No. 91/49

Nick VRIEND

Market-Making and Decentralized Trade

ECO No. 91/50

Jeffrey L. COLES/Peter J. HAMMOND

Walrasian Equilibrium without Survival:

Existence, Efficiency, and Remedial

Policy
ECO No. 91/51

Frank CRITCHLEY/Paul MARRIOTT/ Mark SALMON

Preferred Point Geometry and Statistical Manifolds

ECO No. 91/52

Costanza TORRICELLI

The Influence of Futures on Spot Price

Volatility in a Model for a Storable

Commodity

ECO No. 91/53

Frank CRITCHLEY/Paul MARRIOTT/

Mark SALMON

Preferred Point Geometry and the Local Differential Geometry of the Kullback-

Leibler Divergence

ECO No. 91/54

Peter MØLLGAARD/

Louis PHLIPS

Oil Futures and Strategic

Stocks at Sea

ECO No. 91/55

Christian DUSTMANN/

John MICKLEWRIGHT

Benefits, Incentives and Uncertainty

ECO No. 91/56

John MICKLEWRIGHT/

Gianna GIANNELLI

Why do Women Married to Unemployed

Men have Low Participation Rates?

ECO No. 91/57

John MICKLEWRIGHT

Income Support for the Unemployed in Hungary

ECO No. 91/58

Fabio CANOVA

Detrending and Business Cycle Facts

ECO No. 91/59

Fabio CANOVAV

Jane MARRINAN

Reconciling the Term Structure of Interest Rates with the Consumption Based ICAP Model

ECO No. 91/60

John FINGLETON

Inventory Holdings by a Monopolist Middleman 


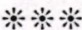

ECO No. 92/61

Sara CONNOLLY/John

MICKLEWRIGHT/Stephen NICKELL

The Occupational Success of Young Men

Who Left School at Sixteen

ECO No. 92/62

Pier Luigi SACCO

Noise Traders Permanence in Stock

Markets: A Tâtonnement Approach.

I: Informational Dynamics for the Two-

Dimensional Case

ECO No. 92/63

Robert J. WALDMANN

Asymmetric Oligopolies

ECO No. 92/64

Robert J. WALDMANN/Stephen

C. SMITH

A Partial Solution to the Financial Risk and Perverse Response Problems of Labour-Managed Firms: Industry-

Average Performance Bonds

ECO No. 92/65

Agustín MARAVALL/Víctor GÓMEZ

Signal Extraction in ARIMA Time Series Program SEATS

ECO No. 92/66

Luigi BRIGHI

A Note on the Demand Theory of the Weak Axioms

ECO No. 92/67

Nikolaos GEORGANTZIS

The Effect of Mergers on Potential

Competition under Economies or

Diseconomies of Joint Production

ECO No. 92/68

Robert J. WALDMANN/

J. Bradford DE LONG

Interpreting Procyclical Productivity:

Evidence from a Cross-Nation Cross-

Industry Panel

ECO No. 92/69

Christian DUSTMANN/John

MICKLEWRIGHT

Means-Tested Unemployment Benefit and Family Labour Supply: A Dynamic Analysis
ECO No. 92/70

Fabio CANOVA/Bruce E. HANSEN

Are Seasonal Patterns Constant Over

Time? A Test for Seasonal Stability

ECO No. 92/71

Alessandra PELLONI

Long-Run Consequences of Finite

Exchange Rate Bubbles

ECO No. 92/72

Jane MARRINAN

The Effects of Government Spending on

Saving and Investment in an Open

Economy

ECO No. 92/73

Fabio CANOVA and Jane MARRINAN

Profits, Risk and Uncertainty in Foreign

Exchange Markets

ECO No. 92/74

Louis PHLIPS

Basing Point Pricing, Competition and

Market Integration

ECO No. 92/75

Stephen MARTIN

Economic Efficiency and Concentration: Are Mergers a Fitting Response?

ECO No. 92/76

Luisa ZANCHI

The Inter-Industry Wage Structure:

Empirical Evidence for Germany and a

Comparison With the U.S. and Sweden

ECO NO. 92/77

Agustín MARAVALL

Stochastic Linear Trends: Models and

Estimators

ECO No. 92/78

Fabio CANOVA

Three Tests for the Existence of Cycles in Time Series

ECO No. 92/79

Peter J. HAMMOND/Jaime SEMPERE Limits to the Potential Gains from Market Integration and Other Supply-Side Policies 
ECO No. 92/80

Víctor GÓMEZ and Agustín

MARAVALL

Estimation, Prediction and Interpolation

for Nonstationary Series with the

Kalman Filter

ECO No. 92/81

Víctor GÓMEZ and Agustín

MARAVALL

Time Series Regression with ARIMA

Noise and Missing Observations

Program TRAM

ECO No. 92/82

J. Bradford DE LONG/ Marco BECHT

"Excess Volatility" and the German

Stock Market, 1876-1990)

ECO No. 92/83

Alan KIRMAN/Louis PHLIPS

Exchange Rate Pass-Through and Market

Structure

ECO No. 92/84

Christian DUSTMANN

Migration, Savings and Uncertainty

ECO No. 92/85

J. Bradford DE LONG

Productivity Growth and Machinery

Investment: A Long-Run Look, 1870-

1980

ECO NO. 92/86

Robert B. BARSKY and J. Bradford

DE LONG

Why Does the Stock Market Fluctuate?

ECO No. 92/87

Anthony B. ATKINSON/John

MICKLEWRIGHT

The Distribution of Income in Eastern

Europe

ECO No.92/88

Agustín MARAVALL/Alexandre

MATHIS

Encompassing Unvariate Models in Multivariate Time Series: A Case Study

ECO No. 92/89

Peter J. HAMMOND

Aspects of Rationalizable Behaviour
ECO 92/90

Alan P. KIRMAN/Robert

J. WALDMANN

I Quit

ECO No. 92/91

Tilman EHRBECK

Rejecting Rational Expectations in Panel

Data: Some New Evidence

ECO No. $92 / 92$

Djordje Suvakovic OLGIN

Simulating Codetermination in a

Cooperative Economy

ECO No. 92/93

Djordje Suvakovic OLGIN

On Rational Wage Maximisers

ECO No. 92/94

Christian DUSTMANN

Do We Stay or Not? Return Intentions of

Temporary Migrants

ECO No. 92/95

Djordje Suvakovic OLGIN

A Case for a Well-Defined Negative

Marxian Exploitation

ECO No. 92/96

Sarah J. JARVIS/John

MICKLEWRIGHT

The Targeting of Family Allowance in Hungary

ECO No. 92/97

Agustín MARAVALL/Daniel PEÑA

Missing Observations and Additive

Outliers in Time Series Models

ECO No. 92/98

Marco BECHT

Theory and Estimation of Individual and

Social Welfare Measures: A Critical

Survey

ECO No. 92/99

Louis PHLIPS and Ireneo Miguel

MORAS

The AKZO Decision: A Case of

Predatory Pricing?

ECO No. 92/100

Stephen MARTIN

Oligopoly Limit Pricing With Firm-

Specific Cost Uncertainty 
ECO No. 92/101

Fabio CANOVA/Eric GHYSELS

Changes in Seasonal Patterns: Are They Cyclical?

ECO No. 92/102

Fabio CANOVA

Price Smoothing Policies: A Welfare

Analysis

\section{粠洸}

ECO No. 93/1

Carlo GRILLENZONI

Forecasting Unstable and Non-Stationary Time Series

ECO No. 93/2

Carlo GRILLENZONI

Multilinear Models for Nonlinear Time

Series

ECO No. 93/3

Ronald M. HARSTAD/Louis PHLIPS

Futures Market Contracting When You

Don't Know Who the Optimists Are

ECO No. 93/4

Alan KIRMAN/Louis PHLIPS

Empirical Studies of Product Markets

ECO No. 93/5

Grayham E. MIZON

Empirical Analysis of Time Series:

Illustrations with Simulated Data

ECO No. 93/6

Tilman EHRBECK

Optimally Combining Individual

Forecasts From Panel Data

ECO NO. 93/7

Víctor GÓMEZ/Agustín MARAVALL Initializing the Kalman Filter with Incompletely Specified Initial Conditions

\section{ECO No. 93/8}

Frederic PALOMINO

Informed Speculation: Small Markets

Against Large Markets

ECO NO. 93/9

Stephen MARTIN

Beyond Prices Versus Quantities
ECO No. 93/10

José María LABEAGA/Angel LÓPEZ

A Flexible Demand System and VAT

Simulations from Spanish Microdata

ECO No. 93/11

Maozu LU/Grayham E. MIZON

The Encompassing Principle and

Specification Tests

ECO No. 93/12

Louis PHLIPS/Peter MØLLGAARD

Oil Stocks as a Squeeze Preventing

Mechanism: Is Self-Regulation Possible?

ECO No. 93/13

Pieter HASEKAMP

Disinflation Policy and Credibility: The

Role of Conventions

ECO No. 93/14

Louis PHLIPS

Price Leadership and Conscious

Parallelism: A Survey

ECO No. 93/15

Agustín MARAVALL

Short-Term Analysis of Macroeconomic Time Series

ECO No. 93/16

Philip Hans FRANSES/Niels

HALDRUP

The Effects of Additive Outliers on Tests for Unit Roots and Cointegration

ECO No. 93/17

Fabio CANOVAJJane MARRINAN

Predicting Excess Returns in Financial Markets

ECO No. 93/18

Iñigo HERGUERA

Exchange Rate Fluctuations, Market

Structure and the Pass-through

Relationship

ECO No. 93/19

Agustín MARAVALL

Use and Misuse of Unobserved

Components in Economic Forecasting 
ECO No. 93/20

Torben HOLVAD/Jens Leth

HOUGAARD

Measuring Technical Input Efficiency for

Similar Production Units:

A Survey of the Non-Parametric

Approach

ECO No. 93/21

Stephen MARTIN/Louis PHLIPS

Product Differentiation, Market Structure

and Exchange Rate Passthrough 
